managed to summarize so much material, and the success of the chairmen (Profs. G. V. Raynor and A. G. Quarrell) in keeping speakers to their allocated times. The papers and discussion will be published in the Monograph and Report Series of the Institute of Motals.

J. W. Christian

\section{BIOLOGISTS AND NATIONAL SERVICE}

T

HE Institute of Biology has made inquiries of the Miristry of Labour and National Service about the opportunities open to graduate biologists in the Services (J. Inst. Biol., 3, No. 1; November 1955). The position appears to be as follows. All science and engineering graduates entering the Forces aro considered for National Service commissions, and in the past about 40 per cent of them have been commissioned during their National Service. Both in the Royal Navy and the Royal Air Force, science graduates are accepted for National Service only if they can be recommended by a pre-call-up officers' selection board for a National Service commission. In the Army all graduates are called up in the ranks; but each is given an opportunity of being considered for a National Service commission during the period of his basic training.

There are comparatively few opportunities for a graduate in the biological sciences to be employed in any of the three Services in a capacity which will make direct use of his qualifications. So far as the Navy is concerned, his acceptance is unlikely. The demands of the Navy are mainly for mechanical and electrical engineers, mathematicians and physicists, and it does not usually have any requirement for graduates in the biological sciences. In the Royal Air Force, a comparatively small number of graduates in biology is accepted for National Service commissions in the Education Branch. It is also open to any National Service recruit to opt for service in the General Duties Branch for training as a pilot.

The War Office has recommended that a graduate in the biological sciences should apply for service in either the Royal Corps of Signals, the Royal Artillery, the Royal Engineers or the Royal Armoured Corps, where his scientific background is likely to be particularly valuable. There is, of course, nothing to prevent a science graduate from applying for service in any branch, technical or non-technical, and acceptance for a commission will depend solely on qualities of leadership and character and does not depend on technical or academic qualifications, except in so far as a potential officer must be intelligent and able to express himself clearly. Com missions in the Royal Army Education Corps are not given to National Service men; but a graduate in biology, especially if he holds the postgraduate Certificate of Education, may elect to do his service in that Corps where he could expect to be appointed sergeant instructor. The Royal Army Medical Corps is normally officered by medically qualified men; but an occasional vacancy occurs for a physiologist, biochemist or entomologist in commissioned rank. Otherwise, biology graduates may be appointed as laboratory technicians or in similar posts, and promotion to sergeant rank is possible.

An increasing number of science graduates now apply for short-service commissions as an alternative to National Service. These are voluntary regular engagements and usually involve a minimum of three years full-time service. Short-service commissions are available for science (including biology) graduates in the Education Branch of the Royal Air Force or in the Royal Army Educational Corps, as well as in other branches of the Royal Air Force and the Army.

There is no 'allocation' of scientists to defence work; but there is a number of projects of high priority carried on by government departments and private firms on which science graduates may be employed and given deferment on the applications of the government department concerned. Most of the vacancies are for physicists, mathematicians, chemists and engineers: biologists are required only on rare occasions. Deferment can also be granted for certain appointments in the Colonial Agricultural Service, for which biologists are much more in demand.

\section{INTERNATIONAL SURVEY OF PROGRAMMES OF SOCIAL DEVELOPMENT}

YN accordance with a resolution of the United Nations Economic and Social Council, the Bureau of Social Affairs of the United Nations Secretariat, in co-operation with the International Labour Office, the United Nations Educational, Scientific and Cultural Organization, the Food and Agriculture Organization and the World Health Organization, has prepared a survey of national and international measures taken to improve social conditions throughout the world*. Entitled "International Survey of Programmes of Social Development", it is concerned primarily with measures taken since 1945 , and with those taken by governments rather than by voluntary or private organizations, and is intended to supplement the "Preliminary Report on the World Social Situation". The survey brings out the remarkable recent expansion of such programmes throughout the world, an expansion which has necessitated the report being limited to the outlining of trends and developments, using concrete cases only for illustrative purposes. The report should be particularly useful to all concerned with Colonial development and welfare and with technical assistance generally, whether under the Colombo Plan or in other ways.

An introductory chapter reviewing the similarities and differences in national approaches to social welfare, production and rural development points out that, in practically all the types of programme surveyed, the three problems constantly being encountered are those of obtaining adequate personnel to execute the programmes, adequate informa. tion to guide them, and adequate resources to finance them. Shortages of trained personnel are experienced by countries at all levels of development. Training abroad on fellowships has made an important but limited contribution to the supply of the higher-level technical and professional workers in some countries; attempts have been made in many countries to deal with the maldistribution among the professions, and

* International Survey of Programmes of Social Development. Pp. iv +200 (New York: United Nations; London: H.M.S.0. 1955.) 2 dollars, 15s., 8 Sw. fr. 